\title{
DASAR DAN KONSEP MANAJEMEN PENDIDIKAN PERSPEKTIF AL-QUR'AN
}

\author{
Achmad Fauzi \\ ac.fauzi25@yahoo.com \\ (Dosen Fakultas Agama Islam, Universitas Muhammadiyah Tangerang)
}

\begin{abstract}
Abstrak:
Dasar dan Konsep Manajemen Pendidikan Perspektif Al-Qur'an adalah Konsep manajemen yang berorientasi pada; 1) Fleksibel, Manajemen dikatakan fleksibel apabila manajemen itu dapat menyesuaikan diri dengan berbagai situasi dan kondisi. 2) Efektifefisien, Suatu manajemen pendidikan dikatakan efektif-efisien jika mempunyai ciri:Tujuan yang jelas, Mengkreasikan alternatif-alternatif, Mengoptimalkan sumber-sumber pendidikan, Memperoleh hasil pendidikan, Meningkatkan keuntungan pendidikan. 3) Terbuka, terbuka kesempatan kepada semua pihak, terutama staf untuk mengembangkan diri sesuai dengan kemampuannya baik dalam jabatan maupun bidang lainnya. 4) kooperatif dan partisipatif, diperlukan adanya manajer yang handal yang mampu membuat perencanaan yang baik, mengorganisir, menggerakkan dan melakukan kontrol serta tahu kekuatan (strength), kelemahan (weakness), kesempatan peluang (opportunity) dan ancaman (theat) hendaknya sesuai maka orang yang diberi amanat untuk memenaj lembaga pendidikan Islam sesuai dengan ajaran al-Qur'an.
\end{abstract}

\section{Kata Kunci: Dasar, Konsep, Menajemen, al-Qur'an}

\section{A. Pendahuluan}

Manajemen pendidikan upaya untuk melakukan pengelolaan secara ter-struktur terkait bidang pendidikan. Fungsi yang ada dalam manajemen pendidikan itu terdiri dari perencanaan atau planning guna kegiatan dapat berjalan dengan lebih sistematis. Kemudian pengorganisasian atau organizing sebagai sisi untuk dapat melakukan pembagian dari tugas yang ada. Lalu ada fungsi pergerakan atau actuating sebagai realisasi dari rencana dan organisir yang telah dibuat di awal. Pergerakan lebih untuk memberikan semangat agar dapat mencapai tujuan dari manajemen pendidikan yang ada. Manajemen pendidikan adalah kegiatan untuk mengumpulkan beberapa sumber terkait dunia pendidikan. sehingga dapat difokuskan untuk menuju pada tujuan yang sudah ditetapkan sesuai dengan pendidikan yang diharapkan. Manajemen pendidikan secara umum adalah manajemen yang perlu dilakukan perencanaan terlebih dahulu. Manajemen juga merupakan organisir agar dapat sampai pada tujuan. Termasuk mengarah pada perlunya pengawasan yang terarah agar manajemen pendidikan tidak keluar dari tujuan yang ingin dicapai. Konsep manajemen pendidikan yang mengacu pada dasar ilmu, maka ilmu yang perlu diberikan dalam manajemen pendidikan haruslah sesuai dengan yang ada konsep manajemen pendidikan yang mengacu pada dasar seni, maka ilmu yang perlu diberikan dalam manajemen pendidikan haruslah membekali peserta didik lebih terampil. Tidak sekadar pintar saja. Konsep manajemen pendidikan yang mengacu pada dasar proses, maka jelas setiap tindakan dan usaha itu perlu proses. 


\section{B. Dasar dan Konsep Manajemen Pendidikan Perspektif Al-Qur'an}

Ajaran islam sesungguhnya sudah meletakan dasar-dasar manajemen pendidikan Islam, dan hal itu tersimpan dengan baik dalam dokumen-dokumen sejarah Islam yang primer dan sekunder, banyak sarjana Muslim sebelum meneliti dan mengungkapnya khususnya Muslim di Indonesia, berawal dari kesadaran terhadap problem tersebut, pada dasar-dasar menejemen perspektif al-Qur'an terdapat nilai-nilai normatife dan historis Islam antara lain adalah:

1. Merujuk kepada literature-literatur yang kridibel dan akurat. Dengannya akan didapatkan sebuah produk pendidikan yang multidimensional dan polyinterpretabel, sehingga dapat diabestrakkan pada berbagai fragmen manajemen pendidikan. Pendidikan Islam senantiasa merujuk pada dokumen primer yakni al-Qur'andan as-Sunah, dengan tidak mengabaikan peranan dokumen sekunder seperti hadits, ijma, qiyas dan lain yang termaktub dalam buku-buku para intelektual Muslim awal (salaf). Hasilnya oaut put dan outcome pendidikan akan lebih mampu survese dan kompetetisi.

2. Penanaman keikhlasan dan ketulusan dalam proses pendidikan, baik kepada peserta didik, praktisi pendidikan dan seluruh bagian yang terintegrasi dan bersinergi dengan institusi maupun lingkungan pendidikan. Terjadinya ketulusan dalam menjalankan pendidikan, akan melahirkan kegagalan pencapaian tujuan pendidikan. Nabi Muhammad SAW telah menyebutkan:

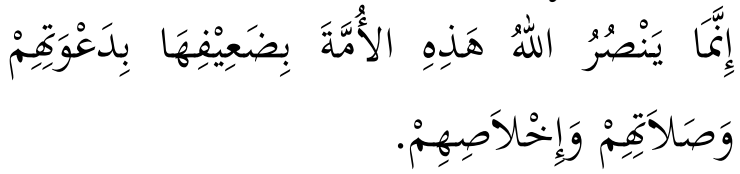

"Sesungguhnya Allah hanya akan menolong umat ini dengan orang-orang yang lemah di antara mereka, dengan doa mereka, sholat mereka dan keikhkasan mereka".

Materi yang pertama diajarkan kepada peserta didik adalah materi fundamental, seperti pengenalan hurufhuruf, operasi hitung, cara menulis, bahasa, baik bahasa lokal maupun bahasa asing, yang menjadi alat dan modal awal untuk proses belajar selanjutnya. Pembelajaran ini tampak pada aksentuasisasi yang dilakukan oleh Rasulullah SAW sebagai seorang manajer pendidikan dimasa awal islam dimana beliau melakukan tashfiyyah atau perivikasi ideologi jahiliyah (ignorance ideology) dan materi pendidikan yang mengalami penyimpangan (deviation) yang telah menjadi kebiasaan pada mayoritas masyarakat sosial Arab kala itu. Yang pertama kali Nabi Muhammad SAW mengsosialisasikan adalah materi tentang keimanan, sebab hal itulah yang paling mendasar dalam kontruksi agama Islam.

Seperti ini juga diterapkan oleh generasi-generasi berikutnya, seperti tersurat dalam penuturan jundub "kami belajar tentang iman sebelum belajar alQur'an, kemudian belajar al-Qur'an sehingga dengannya bertambah iman kami”

Disini didapatkan poin lanjutan, bahwa dalam proses pendidikan sistem jenjang dan proses menjadi sangat berarti bagi keberhasilan manajemen pendidikan. Tanpa sistem jenjang akan ditemukan kesulitan untuk mengetahui pencapaian, tanpa prioritas akan menimbulkan ketidak beraturan dan kemunduran intelektual. Kita sangat berterima kasih kepada pendahulu kita atas jasa-jasa meraka yang melakukan formalisasi materi sehingga mudah menjalankan kegiatan pendidikan.

${ }^{1}$ Shahih Imam Bukhori No. 2896 dan Shahih Al-Jami' No. 2388 
Berpedoman pada methode ilmiah dengan menggunakan sarana berpikir dengan berlandaskan hujjah (bukti yang valid), melalui penelusuran yang intensif dan berkelanjutan. Prinsip ini memiliki peranan penting dalam menjaga kemurnian ilmu dari kontaminasi yang bukan ilmu. Karena ilmu adalah pengetahuanpengetahuan yang lahir dari akal sehat yang terdidik. Melalui mathode ilmiah dengan bekal saranaberpikir ilmiah berdasarkan empirisme dan rasionalisme secara induktif dan deduktif.

Al-Qur'anul Karim sebagai kitab suci kaum Muslimin antara lain berfungsi sebagai "Hudan" sarat dengan berbagai petunjuk agar manusia menjadi khalifah dimuka bumi. Untuk memperoleh petunjuk tersebut diperlukan pengkajian terhadap alQur'an itu sendiri. Sehingga kaum Muslimin benar-benar bisa mengambil manfaat yang sebesar-besarnya dari isi kandungan al-Qur'an tersebut yang didalamnya kaya dengan permasalahanpermasalan yang sudah terjadi, maupun yang belum terjadi. Semua hal yang berkaitan dengan kehidupan manusia dari dulu sampai kini dan yang akan datang, sesungguhnya sudah termaktub dalam AlQur'an, termasuk permasalahan asal usul manusia sampai pada aktivitas yang boleh dan tidak boleh dilakukan, yang baik dan buruk, serta pola hubungan manusia dengan khalikNya, dengan alam dan terutama sesama manusia dapat dijumpai dalam al-Qur'an.

Sumber daya yang dimobilitasi dan dipadukan untuk mancapai tujuan pendidikan tersebut tentunya meliputi; manusia, dana dan sarana prasarana (man, money dan material) dan semua itu tidak hanya terbatas yang ada di madrasah saja, tetapi juga yang terdapat dalam lingkungan madrasah secara lebih luas. Berkomunikasi bekerja sama dengan berbagai pihak yang terkait baik internal maupun eksternal sangat membantu dan menentukan kemajuan madrasah dan semua itu memerlukan ilmu manajemen.

Karena manajemen merupakan bagian dari kegiatan suatu institusi lembaga ataupun organisasi yang sangat penting, tentunya harus dilaksanakan secara baik dan menyeluruh. Begitu pula dalam lembaga pendidikan, manajemen menjadi suatu alat dalam menciptakan tujuan pendidikan. Manajemen yang baik adalah manajemen yang tidak jauh menyimpang dari konsep dan yang sesuai dengan obyek yang ditangani dan tempat organisasi itu berada. Karena manajemen merupakan suatu ilmu, maka seharusnya tidak menyimpang dari konsep manajemen yang sudah ada. Begitu pula dengan masing-masing organisasi memiliki situasi dan kondisi yang berbeda yang membutuhkan syarat tersendiri untuk menanganinya.

Jika dikaitkan dengan manajemen pendidikan Islam, maka konsep manajemen perspektif al-Qur'an adalah; fleksibel, efektif-efisien, terbuka, serta kooperatif dan partisipatif. ${ }^{2}$

\section{Fleksibel}

Manajemen dikatakan fleksibel apabila manajemen itu dapat menyesuaikan diri dengan berbagai situasi dan kondisi. Manajemen ini tidak kaku dapat berlangsung dalam situasi dan kondisi yang berbeda. Agar manajemen dapat fleksibel, maka harus didukung dengan nilai-nilai yang baik yaitu dedikasi, keahlian, dan otoritas. Dedikasi menunjukkan pengabdian mereka kepada organisasi, keahlian yang diperoleh melalui pendidikan merupakan bekal dalam bekerja sedangkan otoritas memudahkan mereka dalam bertindak.

Suprayogo, menyatakan bahwa berdasarkan hasil pengamatannya walaupun sifatnya masih terbatas,

${ }^{2}$ Nanang Fattah, Landasan Manajemen Pendidikan, Bandung: Rosda Karya, 2009. h.12. 
menunjukan bahwa sekolah atau madrasah yang meraih prestasi unggul justru karena fleksibelitas pengelola atau manajernya dalam menjalankan tugas-tugasnya. ${ }^{3}$ Jika diperlukan pengelola atau manajer harus berani mengambil kebijakan atau memutuskan hal-hal yang berbeda dengan tuntutan atau petunjuk formal dari atasannya. Jika ini dilakukan maka kualitas manajemen dalam hal ini kinerja manajer atau pemimpin lembaga pendidikan tidak hanya diukur berdasarkan keterlaksanaan suatu program, tetapi lebih dari itu yaitu sejauh mana pelaksanaan suatu program menghasilkan lulusan yang kompeten dan memiliki karakter unggul, sesuai keinginan orang tua.

\section{Efektif dan Efisien}

Suatu pekerjaan dikatakan efektif jika pekerjaan itu memberikan hasil yang sesuai dengan kriteria yang ditetapkan semula. Dengan kata lain pekerjaan sudah mampu merealisasikan tujuan organisasi yang dikerjakan.

Efektifitas yang digunakan adalah efektifitas manajer bukan efektifitas pribadi. Efektifitas bisa terwujud bila manajer mampu melaksanakan perannya untuk mencapai tujuan pada waktu yang tepat. Suatu manajemen pendidikan dikatakan efektif jika mempunyai ciri sebagai berikut:

a. Tujuan yang jelas, dalam arti membuat sesuatu sesuai dengan tujuan pendidikan.

b. Mengkreasikan alternatif-alternatif.

c. Mengoptimalkan sumber-sumber pendidikan.

d. Memperoleh hasil pendidikan.

e. Meningkatkan keuntungan pendidikan.

Suatu pekerjaan dikatakan efisien apabila biaya produksi sedikit yang

\footnotetext{
${ }^{3}$ http://drarifin.wordpres.com/2010/07/15,ko nsep perencanaan pendekatan-dan-model perencanaan pendidikan.
}

dikeluarkan dan mendapat hasil semaksimal mungkin.

Manajemen yang efisien mempunyai ciri:

a. Mengerjakan yang benar. Dengan kata lain menjalankan sesuatu sesuai dengan tujuan pendidikan.

b. Menyelesaikan masalah-masalah pendidikan.

c. Mengamankan sumber-sumber pendidikan.

d. Mengikuti tugas-tugas pendidikan.

e. Merendahkan biaya pendidikan. ${ }^{4}$

Seorang manajer sudah diberi otoritas oleh atasannya dan tentunya seorang yang profesional dalam bidangnya. Dengan bekal ini diharapkan ia akan bisa memberikan hasil kerja yang memuaskan. Bila semua pihak sudah merasa puas akan hasil pekerjaannya, berarti manajemen itu sudah efektif dan efisien. Inilah yang harus dituju oleh manajemen pendidikan.

Kedua kata efektif dan efesien selalu bergandengan dalam manajemen kerena manajemen yang efektif saja sangat mungkin terjadi pemborosan. Sedangkan manajemen yang efesien saja bisa berakibat tidak tercapainya tujuan atau rencana yang telah ditetapkan. Ayat alQur'anyang dapat dijadikan acuan keduanya adalah Q.S al-Kahfi ayat 103104

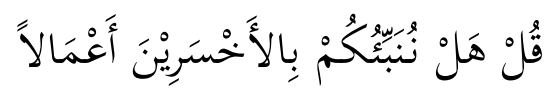

Katakanlah: "Apakah akan Kami beritahukan kepadamu tentang orangorang yang paling merugi perbuatannya?"

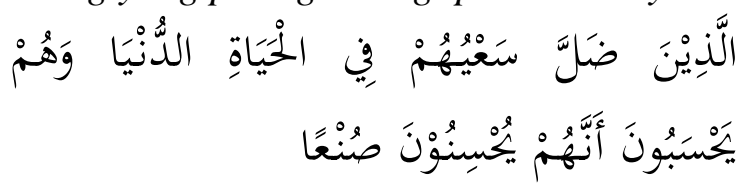

Yaitu orang-orang yang telah sia-sia perbuatannya dalam kehidupan dunia ini, sedangkan mereka menyangka bahwa mereka berbuat sebaik-baiknya.

${ }^{4}$ Made Pidarta, Manajemen Pendidikan Indonesia, Jakarta: Bumi Aksara, 2005,h. 23. 


\section{Terbuka}

Terbuka yang dimaksud disini adalah manajemen yang dikembangkan dalam rangka penanaman nilai-nilai dan pemahaman Islam yang modern, terbuka, toleran serta saling menghargai akan perbedaan yang ada. Selain itu manajemen lebih menghargai hak-hak individu, termasuk kebebasan berpikir, berpendapat dan bebas dari ketakutan. Pendidikan Islam dituntut agar lebih responsif terhadap perubahan yang terjadi. Konsep manajemen terbuka dalam perspektif alQur'an, dapat dilihat dalam Al-Quran(surat al-Baqarah : 30 dan 31), yang dapat disimpulkan menjadi empat yakni; (1) Allah sebagai Penguasa tertinggi memiliki sebuah pandangan/ide ke depan (penciptaan manusia), (2) Allah sebagai Pemimpin menawarkan kepada malaikat untuk memberikan pendapatnya tentang rencana penciptaan manusia (konfirmasi tuk memperoleh solusi terbaik, dalam ranah manusia hal ini diperlukan karena sudut pandang manusia sangatlah terbatas, sehingga diperlukan sudut pandang orang lain), (3) Allah membuka wacana dan memberi contoh tentang dialog dan argument yang diberikan dengan para malaikat (perhatikan alasan malaikat tentang ketidak setujuannya atas penciptaan manusia kemudian perhatikan argumen yang diberikan oleh Allah SWT untuk menyanggah pendapat para malaikat) dan (4) Solusi terbaik diperoleh dengan pemahaman semua pihak atas nilai filosofis atas sebuah keputusan pandangan yang diambil akan dilaksanakan.

Terbuka disini juga diartikan bahwa dalam memberikan informasi dengan benar serta memiliki sifat mau memberi dan menerima saran pendapat orang lain, terbuka kesempatan kepada semua pihak, terutama staf untuk mengembangkan diri sesuai dengan kemampuannya baik dalam jabatan maupun bidang lainnya.
Ayat al-Qur'an yang memerintahkan umat manusia berlaku jujur dan adil yang keduanya merupakan kunci keterbukaan yang terdapat dalam Q.S an-Nisa ayat 58

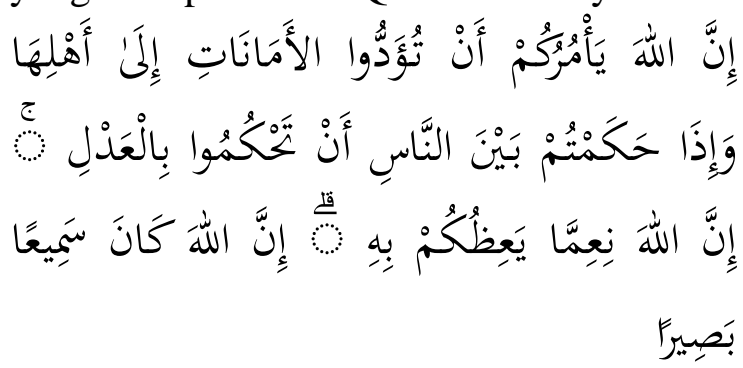

Sesungguhnya Allah menyuruh kamu menyampaikan amanat kepada yang berhak menerimanya, dan (menyuruh kamu) apabila menetapkan hukum di antara manusia supaya kamu menetapkan dengan adil. Sesungguhnya Allah memberi pengajaran yang sebaik-baiknya kepadamu. Sesungguhnya Allah adalah Maha Mendengar lagi Maha Melihat.

Menurut Soetomo dan Sumanto, dalam bukunya Pengantar Operasional Administrasi Sekolah disebutkan, kepala sekolah mempunyai kekuasaan untuk mempengaruhi keefektifan sekolah melalui kepemimpinan dan interaksi meraka. ${ }^{5}$ Serta sekolah yang berhasil adalah yang menejernya selalu berkomunikasi dengan bawahan juga menerima dan meminta masukan dari semua unsur sekolah.

\section{Kooperatif dan Partisipasif}

Dalam rangka melaksanakan tugasnya manajer pendidikan Islam harus kooperatif dan partisipasif. Hal ini disebabkan ada beberapa hal yang menyebabkan mengapa manajemen pendidikan Islam harus bersifat kooperatif dan partisipasif, karena dalam kehidupan tidak dapat melepaskan dari dari berapa limitasi (keterbatasan) yang meliputi:

${ }^{5}$ Hendiat Soetomo dan Wasti Sumanto, Pengantar Operasional Administrasi Sekolah, Surabaya: Usaha Nasional, 2002, hal. 263. 
a) Limitasi fisik (alam) misalkan untuk memenuhi kebutuhan makanan ia harus menanamkan dan ini sering dilakukan invidu atau berkelompok.

b) Limitasi psikologi. Manusia secara psikologi (ilmu jiwa) manusia akan menghargai dan menghormati.

c) Limitasi biologis. Manusia secara biologis termasuk makhluk makhluk yang lemah sehingga untuk memperkuat dan mempertahankan dirinya manusia harus bekerjasama, saling member dan menerima bersatu dan mengadakan ikatan dengan manusia lain.

d) Limitasi sosiologis. Manusia tidak akan dapat hidup tanpa orang lain. ${ }^{6}$

Ayat al-Qur'an yang berkaitan dengan kooperatif dan partisipasif ini antara lain QS. al-Maidah ayat 2.

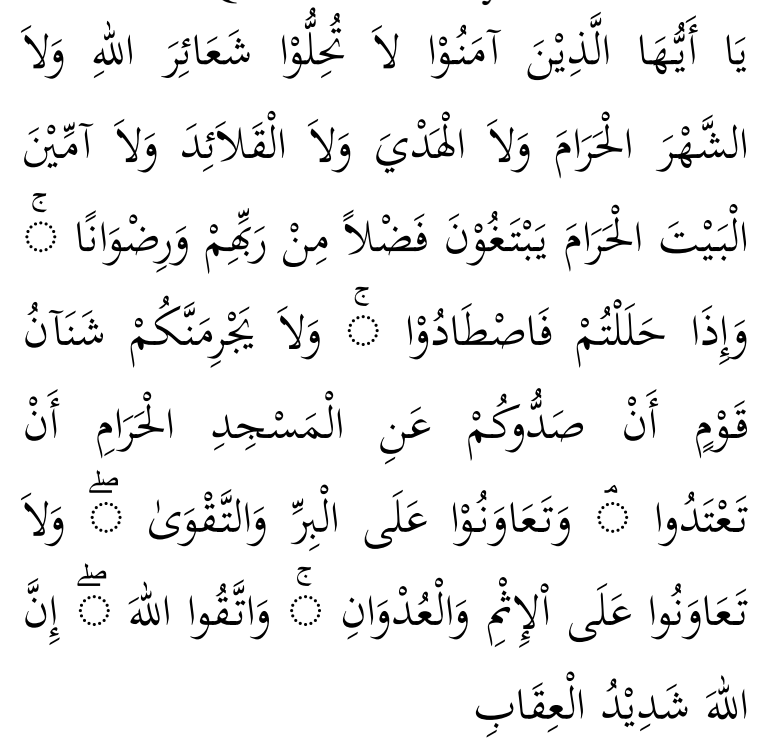

Hai orang-orang yang beriman, janganlah kamu melanggar syi'ar-syi'ar Allah, dan jangan melanggar kehormatan bulanbulan haram, jangan (mengganggu) binatang-binatang had-ya, dan binatangbinatang qalaa-id, dan jangan (pula) mengganggu orang-orang yang

${ }^{6}$ Melayu Hasibuan, Manajemen Dasar: Pengertian dan Masalah, Jakarta: CV Haji Mas Agung, 1989, hal. 41. mengunjungi Baitullah sedang mereka mencari kurnia dan keridhaan dari Tuhannya dan apabila kamu telah menyelesaikan ibadah haji, maka bolehlah berburu. Dan janganlah sekali-kali kebencian(mu) kepada sesuatu kaum karena mereka menghalang-halangi kamu dari Masjidilharam, mendorongmu berbuat aniaya (kepada mereka). Dan tolong-menolonglah kamu dalam (mengerjakan) kebajikan dan takwa, dan jangan tolong-menolong dalam berbuat dosa dan pelanggaran. Dan bertakwalah kamu kepada Allah, sesungguhnya Allah amat berat siksa-Nya (QS. Al-Maidah : 2).

Agar tujuan pendidikan Islam tercapai sesuai dengan yang diharapkan maka diperlukan adanya manajer yang handal yang mampu membuat perencanaan yang baik, mengorganisir, menggerakkan dan melakukan kontrol serta tahu kekuatan (strength), kelemahan (weakness), kesempatan peluang (opportunity) dan ancaman (theat) hendaknya sesuai maka orang yang diberi amanat untuk memenaj lembaga pendidikan Islam sesuai dengan ajaran al-Qur'an.

Manajemen pendidikan Islam merupakan aktifitas untuk memobilisasi dan memadukan dengan segala sumber daya pendidikan islam, dalam rangka untuk mencapai tujuan pendidikan islam yang telah ditetapkan sebelumnya. Sumber daya yang dimobolisasi dan dipadukan untuk mencapai tujuan pendidikan Islam. Dengan perkataan lain dalam merealisasikan semua aspek yang terungkap dalam paparan diatas ternyata tidak lepas dari permasalahan manajemen dan konsep dasar manajemen Islam sendiri sesungguhnya banyak dan mudah ditemukan baik dalam al-Qur'an, maupun hadits Nabi, sehingga jika kita mau mengkaji dan mencarinya, maka berbagai permasalahan terkait pendidikan Islam seperti; kemana arah yang harus dituju, apa saja persoalan yang harus dihadapi, serta 
bagaimana mengatasinya, kekuatan apa yang harus dijalankan dan bagaimana mencapai tujuan pendidikan Islam, dapat ditemukan jawabannya dalam al-Qur'an, dan hadits Nabi Muhammad SAW tentang manajemen.

Yang perlu diingat bahwa Nabi Muhammad SAW, sendiri ternyata seorang manajer yang sangat efektif, sebagaimana kajian, Jawwad, yang menemukan setidaknya ada enam rahasia keunggulan manajemen Rasulullah, yakni; 1) kemampuan memotivasi tim, 2) sederhana dalam memotivasi, 3) kemampuan berkomunikasi, 4) kemampuan mendelegasikan dan membagi tugas, 5) efektif dalam memimpin rapat, dan 6) kemampuan mengontrol dan mengevaluasi. $^{7}$

\section{Penutup}

Dasar dan Konsep Manajemen Pendidikan Perspektif Al-Qur'an adalah Konsep manajemen yang berorientasi pada fleksibel, efektif-efisien, terbuka, serta kooperatif dan partisipatif;

1. Fleksibel, Manajemen dikatakan fleksibel apabila manajemen itu dapat menyesuaikan diri dengan berbagai situasi dan kondisi. Suprayogo, menyatakan bahwa berdasarkan hasil pengamatannya walaupun sifatnya masih terbatas, menunjukan bahwa sekolah atau madrasah yang meraih prestasi unggul justru karena fleksibelitas pengelola atau manajernya dalam menjalankan tugas-tugasnya

2. Efektif-efisien, Suatu manajemen pendidikan dikatakan efektif-efisien jika mempunyai ciri sebagai berikut:

${ }^{7}$ M. Ahmad Abdul Jawwad, Manajemen Rasulullah; Panduan Sukses Diri dan Oerganisasi, Terj. Khozin Abu Faqih Bandung: PT Syamil Cipta Media, 2006, hal. 19. a. Tujuan yang jelas, dalam arti membuat sesuatu sesuai dengan tujuan pendidikan.

b. Mengkreasikan alternatif-alternatif.

c. Mengoptimalkan sumber-sumber pendidikan.

d. Memperoleh hasil pendidikan.

e. Meningkatkan keuntungan pendidikan.

3. Terbuka, bahwa dalam memberikan informasi dengan benar serta memiliki sifat mau memberi dan menerima saran pendapat orang lain, terbuka kesempatan kepada semua pihak, terutama staf untuk mengembangkan diri sesuai dengan kemampuannya baik dalam jabatan maupun bidang lainnya.

4. kooperatif dan partisipatif, Agar tujuan pendidikan Islam tercapai sesuai dengan yang diharapkan maka diperlukan adanya manajer yang handal yang mampu membuat perencanaan yang baik, mengorganisir, menggerakkan dan melakukan kontrol serta tahu kekuatan (strength), kelemahan (weakness), kesempatan peluang (opportunity) dan ancaman (theat) hendaknya sesuai maka orang yang diberi amanat untuk memenaj lembaga pendidikan Islam sesuai dengan ajaran al-Qur'an.

\section{DAFTAR PUSTAKA}

Al-Qur'an al-Karim.

Bukhari, al-. T.T. Shahîh Bukhari: Kitâb al-Janâiz. Kairo: Dâr al-Hadîts.

Hendiat Soetomo dan Wasti Sumanto, Pengantar Operasional Administrasi Sekolah, Surabaya: Usaha Nasional, 2002 
Melayu Hasibuan, Manajemen Dasar:

Pengertian dan Masalah, Jakarta:

CV Haji Mas Agung, 1989

Made Pidarta, Manajemen Pendidikan Indonesia, Jakarta: Bumi Aksara, 2005

M. Ahmad Abdul Jawwad, Manajemen Rasulullah; Panduan Sukses Diri dan Oerganisasi, Terj. Khozin Abu Faqih Bandung: PT Syamil Cipta Media, 2006

Nanang Fattah, Landasan Manajemen Pendidikan, Bandung: Rosda Karya, 2009. 
Dasar dan Konsep Manajemen Pendidikan Perspektif Al-Qur'an

Rausyan Fikr. Vol. 15 No. 2 September 2019. ISSN. 1979-0074 e-ISSN. 9772580594187 | 2 